Gut, 1978, 19, 898-906

\title{
Preparation of lymphoid cells from small specimens of human gastrointestinal mucosa
}

\author{
R. W. CROFTON ${ }^{1}$, CHARLOTTE COCHRANE, AND D. B. L. MCCLELLAND ${ }^{2}$ \\ From the University Department of Therapeutics, Royal Infirmary, Edinburgh
}

SUMMARY Several methods for the preparation of cell suspensions from human gastrointestinal mucosa were investigated. Satisfactory suspensions were obtained by incubating tissue fragments in a solution of collagenase and hyaluronidase overnight at $4{ }^{\circ} \mathrm{C}$ followed by 30 minutes at $37^{\circ} \mathrm{C}$. The resulting suspension contained large numbers of intact lymphoid cells; in addition, variable amounts of epithelial cells and cell debris were present. A high proportion of the lymphoid cells were shown by immunofluorescence to contain immunoglobulin (mainly $\operatorname{IgA}$ ). Viability of these cells was demonstrated by dye exclusion, their ability to survive in short-term culture, and their ability to incorporate radio-labelled amino acid into immunoglobulin in vitro.

There have been many investigations of the function of peripheral blood lymphocytes in patients with disease affecting the gastrointestinal mucosa. However, peripheral blood lymphocytes are not necessarily representative of the lymphocytes in the gut. For example, the relative anergy in Crohn's disease (Meuwissen et al., 1975; Strickland et al., 1975; Meyers et al., 1976) has been attributed to the influx of T-lymphocytes into the bowel wall where they have been identified in large numbers (Meuwissen et al., 1976).

In view of these differences we attempted to isolate lymphoid cells from the gastrointestinal mucosa in order to study their characteristics and function in vitro. There have been several attempts in the past to do this (Nind et al., 1973; Breucha et al., 1974a,b; Mavligit et al., 1974; Clancy, 1976) but in no case have full details been published of the characteristics and properties of the cells isolated. The aim of this study was to develop a method of isolating the lymphoid cells of the human gut mucosa and to permit study of their characteristics and properties.

\section{Methods}

TISSUES

Specimens of stomach, small bowel, or colon were

1Present address: Aberdeen Teaching Hospitals, Aberdeen. ${ }^{2}$ Address for reprints: Dr D. B. L. McClelland, University Department of Therapeutics, Royal Infirmary, Edinburgh EH3 9YW.

Received for publication 17 February 1978 obtained from patients undergoing operation for peptic ulcer and gastric and colonic carcinoma. Specimens of jejunum were obtained by Crosby capsule from patients undergoing investigation for possible coeliac disease. Rectal tissue was obtained by rectal biopsy at sigmoidoscopy. Specimens from patients with carcinoma were obtained as far from the tumour as possible and were macroscopically normal in appearance.

The mucosa and submucosa were dissected free of the muscular layer, washed thoroughly to remove blood and debris, and chopped into fragments about $1 \mathrm{~mm}$ in diameter. Aliquots of $100 \mathrm{mg}$ of tissue were then weighed out.

\section{ENZYMES}

The enzymes used and their source and concentrations are shown in Table 1.

Table 1 Enzymes used in preparing suspensions of mucosal cells

\begin{tabular}{lll}
\hline Enzyme & Source and description & $\begin{array}{l}\text { Concentration } \\
(\mathrm{mg} / \mathrm{ml})\end{array}$ \\
\hline Collagenase & $\begin{array}{l}\text { Sigma: type 1 from Clostridium } \\
\text { histolyticum ammonium sulphate } \\
\text { fraction (cat. no. C 0130) }\end{array}$ \\
Hyaluronidase & $\begin{array}{l}\text { Sigma: type 1 from bovine testes } \\
\text { (cat. no. H 2001) }\end{array}$ & 1.0 \\
Pronase & $\begin{array}{l}\text { BDH: broad spectrum protease } 2.0 \\
\text { from Streptomyces griseus (cat. no. }\end{array}$ \\
& $\begin{array}{l}39052 \text { 2P) } \\
\text { BNH: electrophoretically purified } 0.025 \\
\text { from bovine pancreas (cat. no. }\end{array}$ \\
\hline & 39101 2C) \\
\hline
\end{tabular}




\section{CELL ISOLATION}

All incubations were performed in Hank's balanced salt solution (HBSS) with the $\mathrm{pH}$ adjusted to $7 \cdot 0$ 7.2. Each aliquot of $100 \mathrm{mg}$ tissue was added to $10 \mathrm{ml}$ HBSS containing the appropriate concentration of enzyme in a $20 \mathrm{ml}$ sterile glass universal container. Where indicated, the container was left at $4^{\circ} \mathrm{C}$ overnight. The incubation was performed in a $37^{\circ} \mathrm{C}$ waterbath. A Teflon coated stirring bar was added to the container and the mixture stirred gently on a magnetic stirrer.

At the end of the incubation, the crude cell suspension was filtered through a metal sieve (40 mesh standard) to remove debris. The cells were washed three times in phosphate buffered saline supplemented with a $2.5 \%$ heat-inactivated fetal calf serum, gentamicin $100 \mu \mathrm{g} / \mathrm{ml}$, and nystatin 100 units $/ \mathrm{ml}$. The cells were finally suspended in Ham's F10 medium containing $20 \%$ heat-inactivated pooled normal human serum, gentamicin 100 $\mu \mathrm{g} / \mathrm{ml}$, and nystatin 100 units $/ \mathrm{ml}$. All glassware was sterilised and siliconised before use.

The total cell count was determined in a Neubauer chamber and the viability by exclusion of $0.1 \%$ Trypan blue. Differential counts were carried out on Giemsa-stained preparations made in a Shandon cytocentrifuge using $0.2 \mathrm{ml}$ of cells suspended at a concentration of $10^{5}$ cells $/ \mathrm{ml}$ spun for five minutes at 500 r.p.m.

\section{METHODS OF ISOLATION}

The methods assessed are listed in Table 2. Other methods were also tried but are not listed in this or the following tables because there is only a limited amount of data on them.

Table 2 Methods assessed for preparation of mucosal cell suspensions

1. Stirring in $\mathrm{HBSS}$ for $30 \mathrm{~min}$ at $37^{\circ} \mathrm{C}$

2. Stirring in hyaluronidase $12.5 \mathrm{mg} / \mathrm{ml}$ for $15 \mathrm{~min}$ followed by stirring in pronase $2 \mathrm{mg} / \mathrm{ml}$ for $30 \mathrm{~min}$ at $37^{\circ} \mathrm{C}$

3. Stirring in pronase $2 \mathrm{mg} / \mathrm{ml}$ for $30 \mathrm{~min}$ at $37^{\circ} \mathrm{C}$

4. Soaking in pronase $2 \mathrm{mg} / \mathrm{ml}$ overnight at $4^{\circ} \mathrm{C}$ followed by stirring in pronase $2 \mathrm{mg} / \mathrm{ml}$ and DNAase $0.025 \mathrm{mg} / \mathrm{ml}$ for $30 \mathrm{~min}$ at $37^{\circ} \mathrm{C}$

5. Soaking in collagenase $0.5 \mathrm{mg} / \mathrm{ml}$ and hyaluronidase $1 \mathrm{mg} / \mathrm{ml}$ overnight at $4^{\circ} \mathrm{C}$ followed by stirring for $30 \mathrm{~min}$ at $37^{\circ} \mathrm{C}$

All enzymes were dissolved in HBSS.

* Stirring in $10 \mathrm{ml} / 100 \mathrm{mg}$ tissue in a $20 \mathrm{ml}$ glass universal container with magnetic stirrer.

CELL CULTURE

For cell culture, the cells were suspended in Ham's F10 medium supplemented with human serum and antibiotics as described above. The cell concentration was adjusted to $10^{6}$ viable cells $/ \mathrm{ml}$. Cultures were carried out in rigid polystyrene round-bottom microtitre plates (Flow Laboratories: cat. no.
76-211-05), each well of which contained $0 \cdot 1 \mathrm{ml}$ of the cell suspension (approximately $10^{5}$ viable cells). The plates were sealed and then incubated at $37^{\circ} \mathrm{C}$. At the end of the culture period, the cells were harvested from the wells by aspirating the suspension and washing the wells twice with $0.1 \mathrm{ml}$ PBS, counted and their viability determined. Differential counts were made on cytocentrifuge preparations.

IMMUNOFLUORESCENCE

Alcohol-fixed cytocentrifuge preparations were stained with fluorescein isothiocyanate-conjugated rabbit anti-human IgG, IgA, and IgM antisera (all obtained from Behringwerke). The specificity of the fluorescence was checked by absorbing the antisera with the appropriate immunoglobulin and by blocking the fluorescence with unlabelled antisera. The microscope was a Zeiss Photomicroscope II with incident illumination by an HBO 200 W/4 lamp.

\section{In vitro IMMUNOGLOBULIN SYNTHESIS}

This was assessed by the method originally described by Hochwald et al. (1961). Cell suspensions were incubated in $1 \mathrm{ml}$ modified Eagle's medium containing $1 \mu \mathrm{Ci} / \mathrm{ml}$ each of ${ }^{14} \mathrm{C}$-lysine and ${ }^{14} \mathrm{C}$ isoleucine (both with specific activity greater than $270 \mathrm{~m} \mathrm{Ci} / \mathrm{mmol}$ : Radiochemical Centre), gentamicin $100 \mu \mathrm{g}$ and nystatin 100 units. After 48 hours incubation, the cultures were frozen and thawed, dialysed, lyophilised, and then reconstituted and subjected to micro-immunoelectrophoresis. Carrier proteins as described by Lai A Fat et al. (1976) were used because of the small amount of protein present in the concentrated culture fluid. The antisera used were also as described by Lai A Fat et al. (1976). Autoradiographs were made of the washed and dried immunoelectrophoresis slides.

\section{Results}

CELL PREPARATION METHOD

After an incubation of 30 minutes, fragments of undigested tissue and mucus remained, regardless of which enzyme or enzyme combination was used. Clumping in the cell preparations obscured the cell morphology and made it difficult to obtain accurate cell counts. To try to reduce clumping, EDTA at a concentration of $1 \mathrm{mM} / 1$ was added to the washing medium. However, it only partially succeeded in reducing the clumping and also reduced the total cell yield compared with the normal washing medium.

Incubation periods longer than 30 minutes resulted in lower cell yields. This effect was shown by the action of pronase on peripheral blood lymphocytes. After 30 minutes' incubation, more 
than $95 \%$ were recovered, while after 90 minutes only $22 \%$ were still viable.

After 30 minutes' incubation at $37^{\circ} \mathrm{C}$, considerable numbers of cells remained in the lamina propria when fixed sections of the remaining tissues were examined. It was therefore decided to assess the effect of leaving the tissue in the enzyme solution at $4^{\circ} \mathrm{C}$ overnight in the hope that this would allow better penetration of enzyme into the fragments. This modification gave much better cell preparations and yields with much greater tissue breakdown and little apparent loss of viability in the recovered cells.

The cell yields and the percentage of 'lymphoid' cells obtained are shown in Tables 3 and 4 . In the differential counts, the cells have been classified into epithelial, 'lymphoid', and other cells. Cells termed 'lymphoid' were typical lymphocytes and plasma cells; the 'other' cell category included macrophages,

Table 3 Total yield of cells from gastric mucosa with percentage of 'lymphoid' cells and viability

\begin{tabular}{|c|c|c|c|c|}
\hline Method* & $\begin{array}{l}\text { No. of } \\
\text { samples }\end{array}$ & $\begin{array}{l}\text { Yield } 1100 \mathrm{mg} \\
\pm S E M\end{array}$ & $\begin{array}{l}\text { Per cent } \\
\text { 'Iymphoid' } \\
\text { cells }\end{array}$ & $\begin{array}{l}\text { Per cent } \\
\text { viability }\end{array}$ \\
\hline $\begin{array}{l}\text { Hyal. } \dagger+\text { Pro. } \\
\text { Pro. for } 30 \text { min } \\
\text { Collag. }+ \text { Hyal. } \\
\text { overnight }\end{array}$ & $\begin{array}{r}11 \\
6 \\
7\end{array}$ & $\begin{array}{r}1.03 \pm 0.25 \times 10^{6} \\
1.19 \pm 0.66 \times 10^{6} \\
11.44 \pm 2.20 \times 10^{6}\end{array}$ & $\begin{array}{l}35 \cdot 9 \\
27 \cdot 7 \\
47 \cdot 4\end{array}$ & $\begin{array}{l}83 \\
67 \\
86\end{array}$ \\
\hline
\end{tabular}

* Details of method listed in Table 2 .

†Hyal.: hyaluronidase; Pro.: pronase; Collag.: collagenase.

Table 4 Total yield of cells from small intestinal mucosa with percentage of lymphoid cells and viability

\begin{tabular}{lllll}
\hline Method* & $\begin{array}{l}\text { No. of } \\
\text { samples }\end{array}$ & $\begin{array}{l}\text { Yield/100 mg } \\
\pm S E M\end{array}$ & $\begin{array}{l}\text { Per cent } \\
\text { lymphoid } \\
\text { cells }\end{array}$ & $\begin{array}{l}\text { Per cent } \\
\text { viability }\end{array}$ \\
\hline Stirring & 12 & $6.61 \pm 1.37 \times 10^{6} 32.4$ & 30 \\
Hyal.† + Pro. & 12 & $4.30 \pm 1.09 \times 10^{\circ} 25.6$ & 87 \\
$\begin{array}{l}\text { Pro-overnight } \\
\quad+\text { DNAase }\end{array}$ & 4 & $8.58 \pm 3.07 \times 10^{\circ} 32.4$ & 92 \\
Collag. + Hyal. & 8 & $6.32 \pm 1.06 \times 10^{6} 34.5$ & 87 \\
\hline
\end{tabular}

*Details of method listed in Table 2.

†Key to abbreviations: see Table 3.

eosinophils, mast cells, and cells that could not be identified. Figure 1 illustrates a cytocentrifuge preparation of the cell suspension obtained from a specimen of gastric mucosa, in which cells with the appearance of plasma cells are recognisable, together with damaged epithelial cells and some cell debris. Figure 2 illustrates a suspension of cells from jejunal mucosa viewed by phase contrast after trypan blue staining. The epithelial cells have taken up the dye, but the mononuclear cells are unstained.

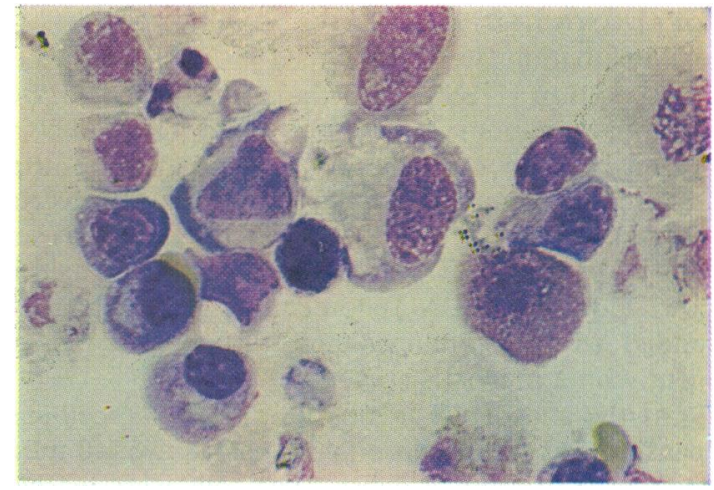

Fig. 1 Cytocentrifuge preparation of cell suspension prepared from human small intestinal mucosa, showing mononuclear cells with the appearance of plasma cells, and damaged epithelial cells. Giemsa $\times 750$.

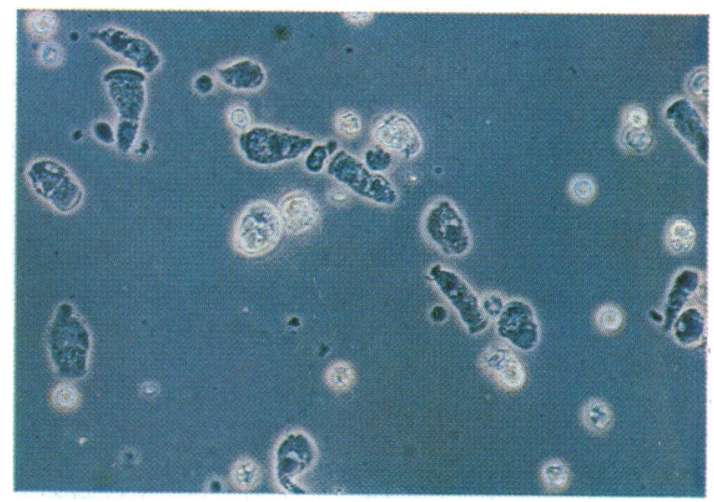

Fig. 2 Cell suspension prepared from small intestinal mucosa. Phase contrast illumination. Trypan blue stained. Many epithelial cells which have taken up dye are present; most mononuclear cells exclude the dye.

With gastric mucosa (Table 3), the yield of $11.4 \times$ $10^{6}$ cells $/ 100 \mathrm{mg}$ was approximately 10 times higher with incubation overnight in the cold followed by 30 minutes at $37^{\circ} \mathrm{C}$ than with other methods. Incubation with collagenase and hyaluronidase for 30 minutes at $37^{\circ} \mathrm{C}$ without overnight incubation in one experiment gave a yield of $4.3 \times 10^{6}$ cells $/ 100$ $\mathrm{mg}$ while collagenase alone for 30 minutes at $37^{\circ} \mathrm{C}$ resulted in $2.7 \times 10^{6}$ cells/100 mg. Other enzymes and enzyme combinations including neuraminidase and trypsin, gave similar yields of $3-4 \times 10^{6}$ cells $/ 100 \mathrm{mg}$. In view of the results with collagenase and hyaluronidase using overnight incubation plus 30 minutes at $37^{\circ} \mathrm{C}$, these other methods were not investigated further.

The results obtained with small intestinal mucosa are listed in Table 4. Regardless of the method used, the total yield of cells was of the range $4.3-8.6 \times$ 
$10^{6}$ cells $/ 100 \mathrm{mg}$ tissue. Other methods which were used on one or two occasions, such as pronase and trypsin, for 30 minutes at $37^{\circ} \mathrm{C}$ or pronase alone with overnight incubation at $4^{\circ} \mathrm{C}$ followed by 30 minutes at $37^{\circ} \mathrm{C}$ gave similar yields but with lower viability or a lower percentage of 'lymphoid' cells. Incubation with collagenase and hyaluronidase in the cold followed by 30 minutes at $37^{\circ} \mathrm{C}$ resulted in the best preservation of cell morphology compared with the other methods along with the highest percentage of lymphoid cells.

A variety of methods of isolating cells from the colon were attempted but none has been satisfactory, giving yields of less than $10^{6}$ cells $/ 100 \mathrm{mg}$ tissue. These cell yields are not presented in detail because the large amount of mucus still present at the end of the incubation period causes cell clumping which makes the counts unreliable.

\section{CELL CULTURE}

The cell suspensions could be satisfactorily maintained in short-term culture. Ten technically satisfactory cultures were set up in microplates. In eight of these cultures, the yield of 'lymphoid' cells after 24 hours' incubation was $50 \%$ or more of the original number of 'lymphoid' cells in the culture. Cells recovered after incubation periods of 24 and 40 hours are illustrated in Fig. 3. The result of a typical experiment is shown in Table 5. This shows that there was a considerable fall in cell numbers in the first 24 hours, after which the cell counts declined slowly.

\section{In vitro IMMUNOGLOBULIN SYNTHESIS}

Nine cultures of stomach and small bowel cell suspensions were set up, each containing $0.5-$ $5.5 \times 10^{6}$ 'lymphoid' cells. The amount of immunoglobulin synthesised was graded on a semi-quantitative scale as described by van Furth et al. (1966). IgA synthesis was detected in seven cultures. The
Table 5 Recovery of 'lymphoid' cells after culture in vitro

\begin{tabular}{lrllr}
\hline $\begin{array}{l}\text { Time } \\
(h)\end{array}$ & Cell number & $\begin{array}{l}\text { Per cent } \\
\text { 'lymphoid, } \\
\text { cells }\end{array}$ & $\begin{array}{l}\text { Number } \\
\text { 'lymphoid' } \\
\text { cells }\end{array}$ & $\begin{array}{l}\text { Per cent } \\
\text { recovery }\end{array}$ \\
\hline 0 & $15.0 \times 10^{5}$ & 87 & $13.1 \times 10^{5}$ & 100 \\
24 & $9.2 \times 10^{5}$ & 87 & $8.0 \times 10^{5}$ & 61 \\
48 & $7.6 \times 10^{5}$ & 91 & $6.9 \times 10^{5}$ & 53 \\
\hline
\end{tabular}

intensity of labelling of the $\operatorname{IgA}$ line tended to increase with the number of 'lymphoid' cells in the culture (Table 6). IgG production was found in six of the cultures and IgM in one. In all these preparations, the intensity of the labelling was much less than that observed for IgA.

Table 6 In vitro synthesis of immunoglobulins and secretory component by cultures of gut lymphoid cells

\begin{tabular}{lllllll}
\hline Source of cells & $\begin{array}{l}\text { Culture } \\
\text { number }\end{array}$ & $\begin{array}{l}\text { Number of } \\
\text { lymphoid } \\
\text { cells in } \\
\text { culture }\end{array}$ & $\begin{array}{l}\text { Intensity of labelling } \\
\text { autoradiograph }\end{array}$ & IgA & IgG & IgM \\
\cline { 3 - 6 } & & $1.1 \times 10^{\circ}$ & \pm & \pm & - \\
\hline Stomach & 530 & $1.1 \times 10^{\circ}$ & \pm & \pm & - \\
& 531 & $0.8 \times 10^{\circ}$ & \pm & - & - \\
& 532 & $5.4 \times 10^{\circ}$ & +++ & \pm & - \\
Small intestine & 554 & $0.4 \times 10^{\circ}$ & - & - & - \\
& 473 & $1.5 \times 10^{\circ}$ & ++++ & \pm & + \\
& 481 & $1.2 \times 10^{\circ}$ & \pm & \pm & - \\
& 551 & $1.5 \times 10^{\circ}$ & \pm & \pm & - \\
\hline
\end{tabular}

IMMUNOFLUORESCENCE

When ethanol-fixed cytocentrifuge preparations were stained with anti-immunoglobulin conjugates, large numbers of $\operatorname{IgA}$ containing cells and small numbers of IgM and IgG containing cells were seen (Fig. 4). With seven specimens, three separate cytocentrifuge preparations were made, one of which was stained with each anti-immunoglobulin antiserum. The total number of fluorescent cells in five high-power fields was counted for each prepara-

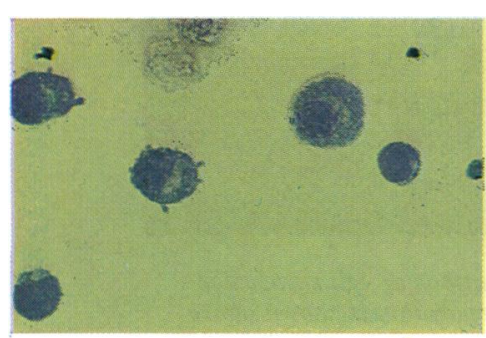

(a)

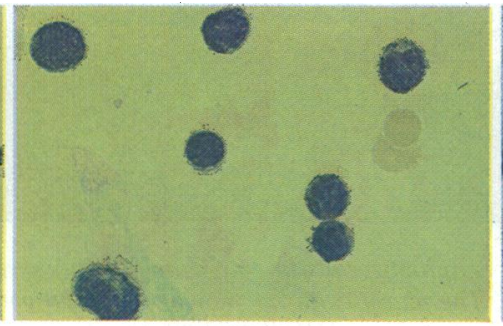

(b)

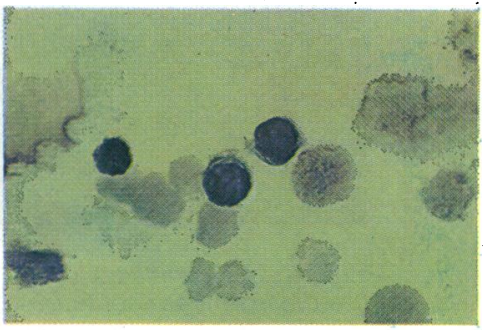

(c)

Fig. 3 Cytocentrifuge preparation of cells from gastric mucosa recovered after culture in microplates. (a and b) Cells removed from culture after 24 hours. (c) After 40 hours in culture the cytoplasmic staining is darker, but both cell types are still present. Giemsa $\times 600$. 


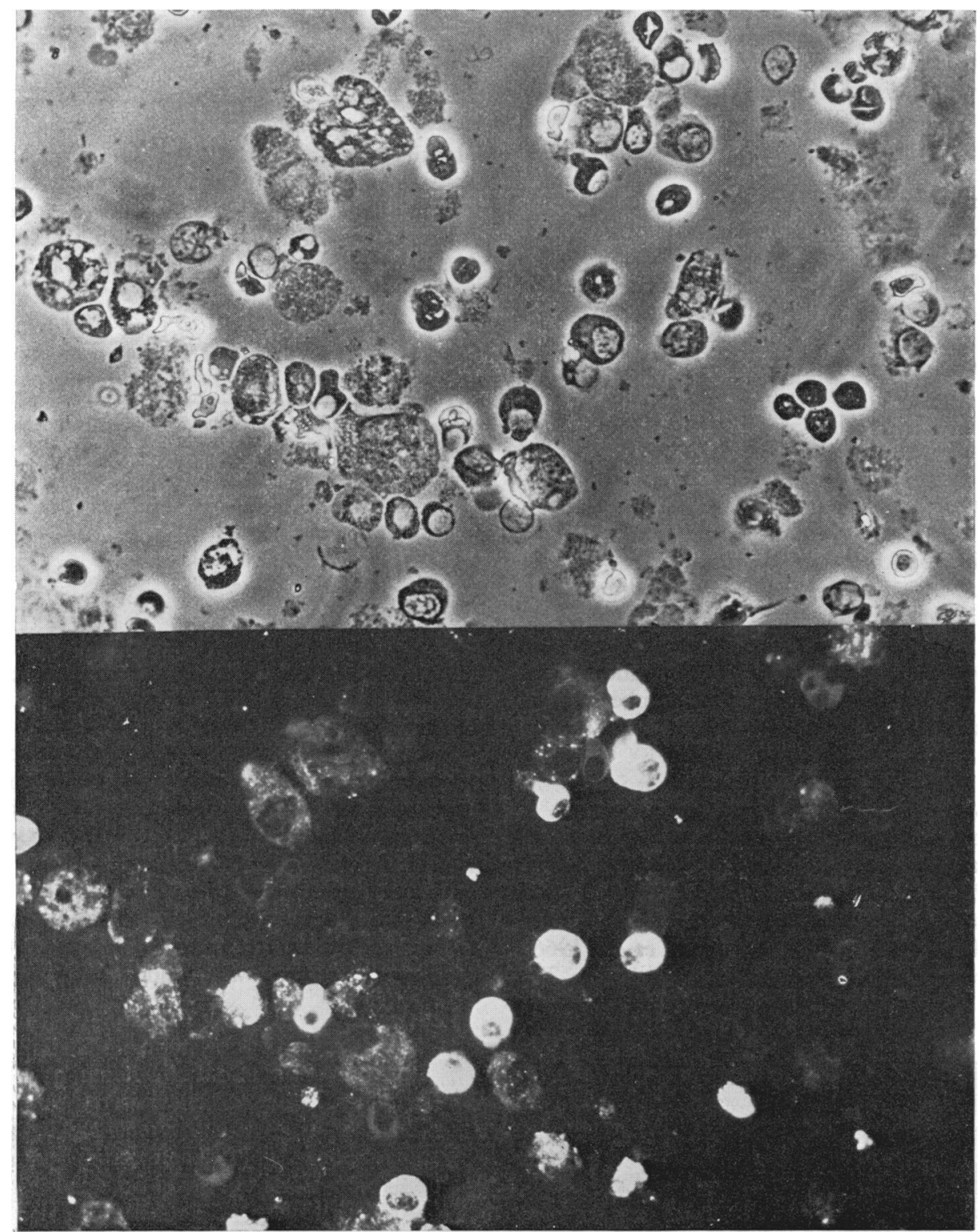

Fig. 4 (a-c) Immunoglobulin containing cells in cytocentrifuge preparations of cell suspensions from human intestinal mucosa. The phase contrast view of the fixed preparation is shown above the same field photographed using incident UV illumination.

(a) Colonic mucosal cells (anti IgA). Intensely fluorescent mononuclear cells are present, and weaker granular fluorescence is seen in some large cells (probably damaged epithelial cells). 


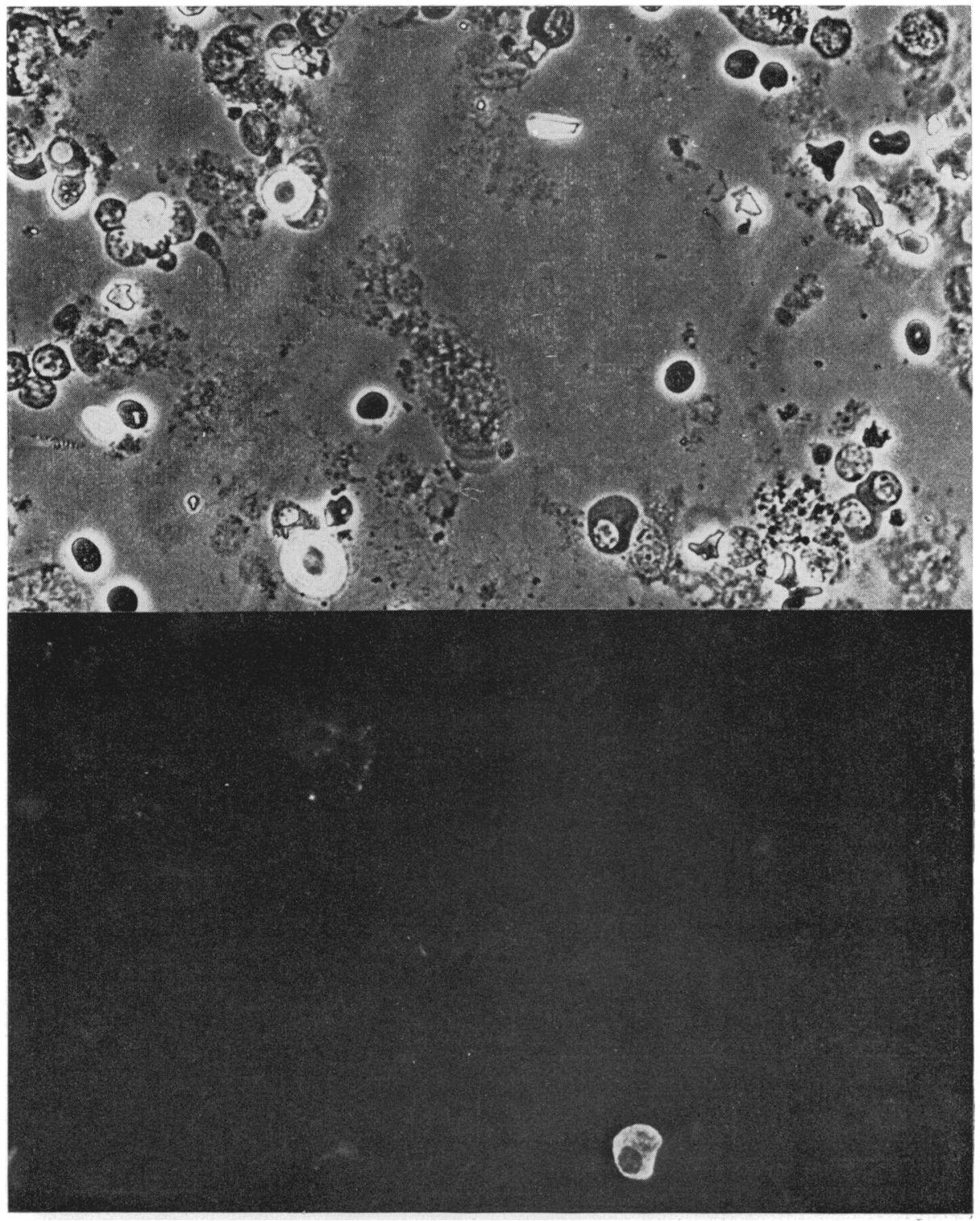

Fig. 4b Colonic mucosal cells (anti IgM). A single intensely fuorescing cell is seen in a field containing both mononuclear and epithelial cells. 


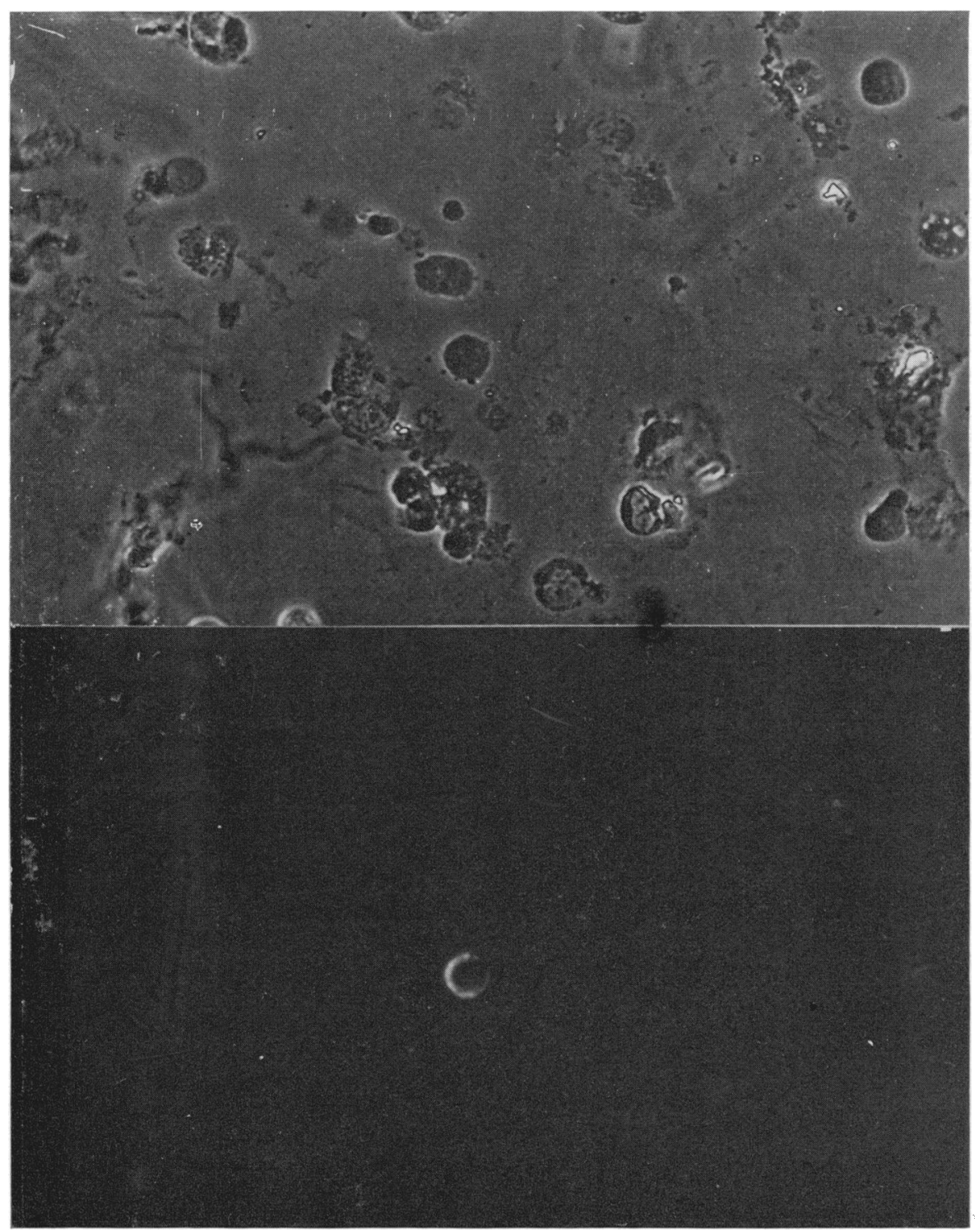

Fig. 4c Small intestinal mucosal cells (anti IgG). A single cell showing cytoplasmic fluorescence is present in this field. 
tion and the ratio of cell numbers for each Ig class determined. In these seven specimens, the ratio of IgA to IgG containing cells ranged from 2.6 to 1 up to 15 to 1 and the IgM to IgG ratios ranged from 0.5 to 1 up to 3.8 to 1 .

An approximation of the percentage of lymphoid cells containing intracellular IgA was obtained by counting the number of fluorescent cells and the total number of cells in at least five high-power fields. The number of IgA cells was then expressed as a percentage of the total number of cells. From the differential counts performed on Giemsa-stained preparations, the percentage of lymphoid cells was known and from these two percentages, the percentage of lymphoid cells which contain IgA was calculated. This came to a mean of $40 \cdot 1 \%$ (SEM \pm $8.7 \%$ ) in 14 preparations.

\section{Discussion}

\section{CELL ISOLATION}

Of all the methods tested, overnight incubation with collagenase and hyaluronidase in the cold followed by stirring for 30 minutes at $37^{\circ} \mathrm{C}$ gave the best results. Other methods described here, or variations of them, failed to give as good total yields or as many viable cells.

Further work is needed to develop a satisfactory method for making cell suspensions from normal colonic mucosa. The two main problems appear to be the very thick layer of mucus and the relatively small numbers of lymphoid cells compared with the stomach and small intestine.

Several other methods of isolating human lymphoid cells from the normal gut have been described but they have failed to give good results in our hands. Nind et al. (1973) worked with cell suspensions prepared from colonic carcinomas, which therefore cannot be assumed to be similar to the lymphocytes present in the normal gut. These workers gave no indication of the cell yield in relation to the weight of the original tissue, nor of the cell type isolated.

Breucha and his colleagues (Breucha et al., 1974a,b) have published two abstracts of methods of isolating gut lymphocytes, one using filtration through a nylon wool column and the other combining that with collagenase treatment. The results have not yet been published in detail. Mavligit et al. (1974) isolated gut lymphocytes by scraping the mucosa and passing the resulting suspensions through a wire mesh. Again, no details of cell yields are given.

Clancy (1976) obtained yields of $10-30 \times 10^{6}$ cells 'per square inch' of mucosa by homogenising the mucosa and filtering the crude suspension through two columns of siliconised glass beads. The final cell preparations contained $97 \%$ lymphocytes but, as no information was provided about cell yields during the separation procedure, the results cannot be compared directly with ours.

In summary, no method of isolation of lymphoid cells of the human gastrointestinal tract has been adequately documented and illustrated. All previous reports omit important information, particularly with respect to cell yields at each point in multistage isolation procedures. Furthermore, in attempts to prepare enriched suspensions of lymphoid cells from mucosa, the possibility has not been excluded that there may be selective enrichment of certain cell types, yielding a final preparation which is not representative of the lymphoid cells present in the mucosa itself. Pretlow et al. (1975) have emphasised the importance of documenting such points in applying any cell separation techniques.

IMMUNOFLUORESCENCE

The data on immunoglobulin-containing cells have been expressed as ratios of IgA: IgG and IgM: IgG. These ratios give only an approximate indication of the relative proportions of the various immunoglobulin-containing cells. To obtain accurate data on the relative proportions of immunoglobulincontaining cells, labelling with two fluorochromes is required as described by Brandtzaeg et al. (1974). However, some points can be made from this preliminary study.

In all cell suspensions, approximately $40 \%$ of the 'lymphoid cells' contained immunoglobulin and the majority of these stained with anti IgA. This is in agreement with the observations of many other workers-for example, Crabbé et al. (1965)-who have shown in sections of normal gut mucosa that the vast majority of immunoglobulin-containing cells stain for IgA. There is no comparable description of suspensions of human gut cells. Rudzik and Bienenstock (1974) studying rabbit mucosa found that only $1 \%$ of a suspension of gut lymphoid cells showed cytoplasmic immunofluorescence (usually $\operatorname{IgA}$ ). This figure is very low in comparison with observations on tissue sections, and suggests that an important selection of cells occurred in the initial separation or subsequent fractionation procedures. In suspensions of mouse lamina propria cells, there were about $20 \%$ IgA plasma cells (Cebra et al., 1977 ) which is comparable with our findings $(40 \cdot 1 \%)$.

IMMUNOGLOBULIN SYNTHESIS

The smallest numbers $\left(0.5-1 \times 10^{6}\right)$ of lymphoid cells used in the cultures synthesised amounts of immunoglobulin which were just detectable by labelling of the autoradiographs. This may be compared with the findings of van Furth (1966) who found that cultures of $1-1.5 \times 10^{6}$ spleen cells synthesised amounts of immunoglobulins which 
were just detectable using a similar technique. Allowing for differences in the lymphoid cell populations in gut and spleen, the amount of $\operatorname{IgA}$ synthesised by $10^{6}$ gut lymphoid cells appears roughly comparable with the amount of IgG produced by a similar number of spleen cells.

In some experiments, the total number of cells isolated from $100 \mathrm{mg}$ fragments were incubated in the culture system. Radioautographs of the supernatant fluids of these cultures showed a similar intensity of labelling to that seen when whole tissue fragments of similar weight were studied in the same system.

\section{CELl CUlTuRE}

It has proved possible to maintain these crude cell preparations in short-term culture. Over the first few hours, there is usually a heavy loss for which three possible explanations have been considered. The first is that the number of viable cells is less than that indicated by Trypan blue exclusion. The second reason is that the cell suspensions contain many dead and dying cells and cell debris which may be cytotoxic and so reduce the number of cells recovered.

It is also likely that a proportion of the cells is not recovered because they have adhered to the microplate and are therefore not harvested at the end of the incubation.

\section{Conclusion}

We have described a satisfactory method for the initial preparation of suspensions of cells from small fragments of human gastrointestinal mucosa. These cells contain and synthesise immunoglobulins and can be maintained in short-term culture. Further work is needed to obtain satisfactory cell yields from the colon. The next stage in this work is to develop methods which will remove epithelial cells from the suspension without selectively depleting subpopulations of lymphoid cells.

We are very grateful to the physicians and surgeons of the Royal Infirmary, Edinburgh who provided us with tissue samples. R. W. Crofton was in receipt of an MRC Training Fellowship. We are also grateful to Miss Christine Gutteridge and Mr R. R. Samson for their excellent technical assistance. Reproduction of the colour photographs was supported by a generous grant from the Carnegie Trust for the Universities of Scotland.

\section{References}

Brandtzaeg, P., Baklien, K., Fausa, O., and Hoel, P. S. (1974). Immunohistochemical characterization of local immunoglobulin formation in ulcerative colitis. Gastroenterology, 66, 1123-1136.

Breucha, G., Rieber, E. P., and Riethmüller, G. (1974a). Characterisation of lymphocytes isolated from human small intestine (Abstract). European Surgical Research, 6, Suppl. 1, 38.

Breucha, G., Riethmüller, G., and Saal, J. (1974b). Gewinnung und Charakterisieurung von Lymphozyten aus gesunden und granulomatös veränderten humanen Dünndarmgeweben. Zeitschrift fur Immunitätsforschung, 147, 333-334.

Cebra, J. J., Gearhart, P. J., Kamat, R., Robertson, S. M., and Tseng, J. (1977). The secretory IgA response in the gut. Biochemical Society Transactions, 5, 1565-1569.

Clancy, R. (1976). Isolation and kinetic characteristics of mucosal lymphocytes in Crohn's disease. Gastroenterology, 70, 177-180.

Crabbé, P. A., Carbonara, A. O., and Heremans, J. F. (1965). The normal human intestinal mucosa as a major source of plasma cells containing $\gamma$ A-immunoglobulin. Laboratory Investigation, 14, 235-248.

van Furth, R. (1966). The formation of immunoglobulins by human tissues in vitro. II. Quantitative studies. Immuno$\log y, 11,13-18$.

van Furth, R., Schuit, H. R. E., and Hijmans, W. (1966). The formation of immunoglobulins by human tissues in vitro. I. The methods and their specificity. Immunology, 11, 1-11.

Hochwald, G. M., Thorbecke, G, J., and Asofsky, R. (1961). Sites of formation of immune globulins and of a component of $\mathrm{C}_{3}$. I. A new technique for the demonstration of the synthesis of individual serum proteins by tissues in vitro. Journal of Experimental Medicine, 114, 459-470.

Lai A Fat, R. F. M., McClelland, D. B. L., and van Furth, R. (1976). In vitro synthesis of immunoglobulins, secretory component, complement and lysozyme by human gastrointestinal tissues. I. Normal tissues. Clinical and Experimental Immunology, 23, 9-19.

Mavligit, G. M., Jubert, A. V., Gutterman, J. U., McBride, C. M., and Hersh, E. M. (1974). Immune reactivity of lymphoid tissues adjacent to carcinoma of the ascending colon. Surgery, Gynecology and Obstetrics, 139, 409-412.

Meuwissen, S. G. M., Feltkamp-Vroom, T. M., Brutel de la Rivière, A., von dem Borne, A. E. G. K., and Tytgat, G. N. (1976). Analysis of the lympho-plasmacytic infiltrate in Crohn's disease with special reference to identification of lymphocyte-subpopulations. Gut, 17, 770-780.

Meuwissen, S. G. M., Schellekens, P. T. A., Huismans, L., and Tytgat, G. N. (1975). Impaired anamnestic cellular immune response in patients with Crohn's disease. Gut, 16, 854-860.

Meyers, S., Sachar, D. B., Taub, R. N., and Janowitz, H. D (1976). Anergy to dinitrochlorobenzene and depression of T-lymphocytes in Crohn's disease and ulcerative colitis. Gut, 17, 911-915.

Nind, A. P. P., Nairn, R. C., Rolland, J. M., Guli, E. P. G., and Hughes, E. S. R. (1973). Lymphocyte anergy in patients with carcinoma. British Journal of Cancer, 28, 108-117.

Pretlow, T. G., II, Weir, E. E., and Zettergren, J. G. (1975). Problems connected with the separation of different kinds of cells. International Review of Experimental Pathology, 14, 91-204.

Rudzik, O., and Bienenstock, J. (1974). Isolation and characteristics of gut mucosal lymphocytes. Laboratory Investigation, 30, 260-266.

Strickland, R. G., Husby, G., Black, W. C., and Williams, R. C., Jr. (1975). Peripheral blood and intestinal lymphocyte sub-populations in Crohn's disease. Gut, 16, 847-853. 